The University of San Francisco

USF Scholarship: a digital repository @ Gleeson Library |

Geschke Center

School of Education Faculty Research

School of Education

2011

\title{
Human Rights Education: Ideology, Location, and Approaches
}

Monisha Bajaj

University of San Francisco, mibajaj@usfca.edu

Follow this and additional works at: http://repository.usfca.edu/soe_fac

Part of the Education Commons

\section{Recommended Citation}

Bajaj, M. (2011). Human Rights Education: Ideology, Location, and Approaches. Human Rights Quarterly. 33, 481-508. DOI: 10.1353/hrq.2011.0019

This Article is brought to you for free and open access by the School of Education at USF Scholarship: a digital repository @ Gleeson Library | Geschke Center. It has been accepted for inclusion in School of Education Faculty Research by an authorized administrator of USF Scholarship: a digital repository@Gleeson Library | Geschke Center. For more information, please contact repository@usfca.edu. 


\title{
Human Rights Education: Ideology, Location, and Approaches
}

\author{
Monisha Bajaj*
}

\begin{abstract}
As human rights education (HRE) becomes a more common feature of international policy discussions, national textbook reform, and post-conflict educational strategies, greater clarity about what HRE is, does, and means is needed. This article reviews existing definitions and models of HRE, and argues that ideology — as much as location or other variables — offers a means of schematizing varying approaches to HRE. This article reviews models organized around principles of global citizenship, coexistence, and transformative action in the context of one nation-state (India), and suggests that the mutability and adaptability of human rights education are its strength.
\end{abstract}

\section{INTRODUCTION}

Over the past four decades, human rights education (HRE) has become a greater part of international discussions of educational policy, ${ }^{1}$ national

\footnotetext{
* Monisha Bajaj is Assistant Professor of Education in the Programs in International and Comparative Education at Teachers College, Columbia University. Her research and teaching interests center on the meanings of education, peace, and human rights education, and educational innovations in the global South. She is also the editor of the Encyclopedia of Peace Education and the author of a Spanish-language teacher-training manual on human rights education. Her forthcoming book is entitled Schooling for Social Change: The Rise and Impact of Human Rights Education in India (Continuum Publishers).

This article benefited greatly from the support of the Institute of Human Rights EducationPeople's Watch, the Centre for Social Justice, and the Indian Institute of Human Rights. Chitra Aiyar, Bikku Kuruvila, and Radhika lyengar provided important input on the development of this article and the National Academy of Education/Spencer Foundation post-doctoral fellowship provided essential support for the research on HRE in India.

1. Francisco O. Ramirez, David Suárez \& John W. Meyer, The Worldwide Rise of Human Rights Education, in School Knowledge in Comparative and Historical Perspective: Changing Curricula in Primary and Secondary Education 35 (Aaron Benavot \& Cecilia Braslavsky eds., 2007).
} 
textbook reform, ${ }^{2}$ and the work of non-governmental organizations (NGOs). ${ }^{3}$ While scholars and practitioners have noted the rise in educational strategies as part of larger human rights efforts and the emergence of HRE on its own as a field of scholarship and practice, ${ }^{4}$ there appear to be diverse perspectives on what exactly HRE is and does (beyond a basic imparting of knowledge of human rights). This article seeks to review various definitions and approaches to HRE, highlight different ideological articulations and practices of HRE, and present examples from international NGOs-particularly Indian NGOs - that advance varied types of instruction in human rights. Data presented in this article are drawn from thirteen months of fieldwork on human rights education initiatives in India by the author from 2008 to 2010; methods included interviews and focus groups with more than 700 respondents involved with HRE and extensive document review of government and NGO materials.

\section{DEFINITIONS AND MODELS OF HUMAN RIGHTS EDUCATION}

\section{A. Some Definitions}

While there are many variants of HRE, there is broad agreement about certain core components of human rights education. First, most scholars and practitioners agree that HRE must include both content and process related to human rights. ${ }^{5}$ Indeed, Felisa Tibbitts finds that "nearly all formal literature associated with HRE will mention the importance of using participatory

2. John W. Meyer, Patricia Bromley \& Francisco O. Ramirez, Human Rights in Social Science Textbooks: Cross-National Analyses, 1970-2008, 83 Soc. Evuc. 111 (2009), available at http://worldpolity.files.wordpress.com/2010/07/meyer-bromley-ramirez-human-rights-intextbooks-soe-may-4-11-10.pdf.

3. Felisa Tibbitts, Human Rights Education, in Encrclopedia of Peace Education 99 (Monisha Bajaj ed., 2008) [hereinafter Tibbitts, Human Rights Education].

4. Anja Mihr \& Hans Peter Schmitz, Human Rights Education (HRE) and Transnational Activism, 29 Hum. Rts. Q. 973 (2007).

5. See Nancy Flowers, What is Human Rights Education?, in A Survey of Human Rights Education (Bertelsmann Verlag ed., 2003); Garth Meintjes, Human Rights Education as Empowerment: Reflections on Pedagogy, in Human Rights Education for the Twenty First Centurr 134 (George J. Andreopoulos \& Richard P. Claude eds., 1997); Betty A. Reardon, Founding Dir. Emeritus, Peace Educ. Ctr., Human Rights Learning: Pedagogies and Politics of Peace, Address at the UNESCO Chair for Peace Education Master Conference (15 Apr. 2009), available at http://www.pdhre.org.HRLreardon.pdf; Norma Tarrow, $\mathrm{Hu}$ man Rights Education: Alternative Conceptions, in Human Rights, Education and Global Responsibilities 21, 22 (James Lynch, Celia Modgil \& Sohan Modgil eds., 1992); Felisa Tibbitts, Understanding What We Do: Emerging Models for Human Rights Education, 48 INT'L Rev. Edu. 159, 161-63 (2002) [hereinafter Tibbitts, Understanding What We Do]. 
methods" for effectively teaching about human rights. ${ }^{6}$ Second, most literature discusses the need for HRE to include goals related to cognitive (content), attitudinal or emotive (values/skills), and action-oriented components. ${ }^{7} \mathrm{Am}$ nesty International's recent Human Rights Friendly Schools framework weaves together the processes of HRE and their intended outcomes by highlighting three prepositions linking education and human rights in a comprehensive manner: education about human rights (cognitive), education through human rights (participatory methods that create skills for active citizenship), and education for human rights (fostering learners' ability to speak up and act in the face of injustices). ${ }^{8}$ Within these broad parameters of convergence, the following section details different definitions and models that have been put forth for HRE over the past six decades.

Definitions of HRE also reflect different histories and conceptions of the field. Article 26 of the Universal Declaration of Human Rights (UDHR) identifies first the right to education and second, the right to an education directed toward "the full development of the human personality and to the strengthening of respect for human rights and fundamental freedoms." ${ }^{\prime 9}$ More recent articulations have elaborated the definition of what HRE is to include and have cited a variety of goals and learners.

As HRE figured more prominently in inter-governmental discussions, the United Nations declared 1995-2004 the International Decade for Human Rights Education. ${ }^{10}$ Drawing on the considerable momentum generated around HRE through the UN Decade, the ongoing World Programme for Human Rights Education was established in 2005 and is housed within the United Nations Office of the High Commissioner for Human Rights. The UN General Assembly also more recently declared 2009 the International Year of Human Rights Learning, ${ }^{11}$ and a UN Declaration on Human Rights Education and Training has been drafted. ${ }^{12}$ As suggested by the United Nations:

6. Felisa Tibbitts, Transformative Learning and Human Rights Education: Taking a Closer Look, 16 Intercultural Educ. 107, 107 (2005) [hereinafter Tibbitts, Transformative Learning].

7. See, e.g., Tibbitts, Transformative Learning, supra note 6. Nancy Flowers, et al., The Human Rights Education Handbook: Effective Practices for Learning, Action, and Change 9 (2000).

8. Amnesty Int'l, Human Rights Friendly Schools Project, available at http://www.amnesty. org/en/human-rights-education/projects-initiatives/rfsp.

9. Universal Declaration of Human Rights, adopted 10 Dec. 1948, G.A. Res. 217A (III), U.N. GAOR, 3d Sess, art. 26, U.N. Doc. A/RES/3/217A (1948).

10. United Nations Decade for Human Rights Education, G.A. Res. 49/184, U.N. GAOR, 59th Sess., U.N. Doc. A/RES/49/184 (1994).

11. International Year of Human Rights Learning, adopted 20 Mar. 2008, G.A. Res. 62/171, U.N. GAOR, 62d Sess. (2008). Some scholars and activists have rejected the term "human rights education" in favor of "human rights learning," citing the latter's emphasis on an inquiry-based perspective, more participatory pedagogy, and less information-centered approach. Betty Reardon has elaborated this distinction. See Reardon, supra note 5.

12. Draft UN Declaration on Human Rights Education and Training, adopted 15 Apr. 2010, G.A. Res. 13/15, , U.N. GAOR, 13th Sess. (2010), available at http://www2.ohchr.org/ english/bodies/hrcouncil/advisorycommittee/HR_education_training.htm. 
$[\mathrm{H}]$ uman rights education can be defined as education, training and information aiming at building a universal culture of human rights through the sharing of knowledge, imparting of skills and moulding of attitudes directed to:

(a) The strengthening of respect for human rights and fundamental freedoms;

(b) The full development of the human personality and the sense of its dignity;

(c) The promotion of understanding, tolerance, gender equality and friendship among all nations, indigenous peoples and racial, national, ethnic, religious and linguistic groups;

(d) The enabling of all persons to participate effectively in a free and democratic society governed by the rule of law;

(e) The building and maintenance of peace;

(f) The promotion of people-centred sustainable development and social justice. ${ }^{13}$

Emphasized in the United Nations definition of HRE is knowledge about human rights and tolerance/acceptance of others based on such knowledge. While NGOs, also active in making the case for the decade and the international year, pushed for the addition of sub-points " $\mathrm{e}$ " and " $\mathrm{f}$ " in 2005 to acknowledge a more active role for individuals and social movements as a result of HRE, the UN definition largely reflects the role of international norms for ensuring social cohesion and peace, and the UN definition is largely directed at national policymakers, a top-down statement of what HRE is and should be. ${ }^{14}$ UN initiatives are largely targeted toward member states, seeking to enlist their commitment towards the integration of HRE in formal schooling, higher education, and professional training.

NGOs have long been active in human rights education and utilize human rights discourse as a strategy to frame the demands of diverse social movements - a more bottom-up approach to HRE. At the grassroots level, HRE has often taken the form of popular education or community education to mobilize constituencies for expanding social movements. ${ }^{15}$ In Latin America, for example, many efforts aimed at HRE blossomed immediately after the end of dictatorships when NGOs that had fought for human rights turned their attention to education as a tool for reconciliation and the prevention of a return to authoritarian rule. ${ }^{16}$ As such, human rights education efforts are seen as both a political and pedagogical strategy to facilitate democratization and active citizenship. ${ }^{17}$

13. United Nations, Plan of Action: World Programme for Human Rights Education 12 (2006).

14. Flowers, supra note 7 .

15. Dip Kapoor, Popular Education and Social Movements in India: State Responses to Constructive Resistance for Social Justice, 37 Convergence 55 (2004).

16. Abraham K. Magendzo, Problems in Planning Human Rights Education for Reemerging Latin American Democracies, in Human Rights Education for the Twenty First Century, supra note 5, at 469 .

17. Id. 
Drawing on the promise of grassroots level efforts to impact awareness about human rights, Amnesty International defines Human Rights Education as the following:

Human rights education is a deliberate, participatory practice aimed at empowering individuals, groups, and communities through fostering knowledge, skills, and attitudes consistent with internationally recognized principles. ... Its goal is to build a culture of respect for and action in the defence and promotion of human rights for all. ${ }^{18}$

The Amnesty International definition places greater responsibility on human rights learners becoming activists for human rights through the process of HRE by sharing information with others and actively working to defend human rights. Both social change as an outcome, and learners becoming agents of this process of claiming their own rights and defending others' rights, are central in this definition. While the differences may be semantic and insignificant to some, approaches to HRE and models for characterizing its outcomes and goals provide further clarity to the ways in which the educational reform is conceptualized and enacted.

\section{B. Existing Models}

Over the past two decades, various models have been advanced for understanding the varied programmatic approaches to HRE. These models provide productive schemas for theorizing the emergence, conceptualization, and implementation of HRE across the globe. One vital forum is the online list-serve and "epistemic community" coordinated by the US-based Human Rights Education Associates (HREA). ${ }^{19}$ As noted by David Suárez, this sphere allows its more than 5,000 members to- "through discourse and active reflection" - "practice, negotiate, refine, and mold HRE." ${ }^{20}$ Populated by many officials of member UN agencies, the discursive engagement on various issues of HRE through the online community has played a salutary role in facilitating international discussions on the topic. Arguably, since many posts are from practitioners seeking advice, materials, or input, the online community can also influence HRE practice as well.

Scholars have also catalogued the types of HRE by the content of the programs, as well as participants' level of engagement. HREA Executive

\footnotetext{
18. Amnesty International, Human Rights Education, available at http://www.amnesty.org/ en/human-rights-education.

19. David Suárez, Education Professionals and the Construction of Human Rights Education, 51 Comp. Educ. Rev. 48 (2007).

20. Id. at 66 .
} 
Director Tibbitts put forth a pyramidal model of differentiated content and constituencies for HRE distinguishing among general "values and awareness", ${ }^{21}$ the "accountability" 22 model for adult professionals directly involved with human rights victims, and the "transformational" 23 model that includes students and community members - a model that is characterized by a greater depth of engagement with issues of rights and justice. ${ }^{24}$ Nancy Flowers elaborates a schema that distinguishes the age of learners with appropriate concepts, goals, and content. ${ }^{25}$

While these models generally offer universal visions for HRE across contexts, other scholars have distinguished HRE by location. For example, scholars have noted the types of societies to explain differences between HRE approaches. ${ }^{26}$ Norma Tarrow highlights how HRE content may be different in "first," "second/socialist," and "third" world contexts based on emphases on individual versus collective rights. Flowers et al. similarly note that different types of rights are emphasized based on context and the perspective of the institution offering HRE; emphases include "survival" or economic/social rights, civil and political rights, activist-oriented education, and moral education that views human rights as part of "natural law." 27 While the variation in content is identified by these scholars based on national context, Tibbitts highlights that HRE is affiliated with different constituencies in different nations:

HRE in post-conflict or post-colonial countries tends to be associated with the rule of law and authorities trying to establish their legitimacy. Among groups that experience a high amount of discrimination, and within countries that are highly repressive and undemocratic, HRE tends to be focused on popular empowerment and resistance in relation to these issues. HRE in countries that are democratic but struggling with development can be oriented towards the infusion of human rights principles within sustainable development. ... In countries that enjoy strong democratic and economic development, HRE is often focused on issues of discrimination, for example in relation to migrants, minorities, or women. ${ }^{28}$

21. Tibbitts, Understanding What We Do, supra note 5, at 163.

22. Id. at 165 .

23. Id. at 166 .

24. Id.

25. Human Rights Here and Now: Celebrating the Universal Declaration of Human Rights 31 (Nancy Flowers ed., 1998); See also Tibbitts, Human Rights Education, supra note 3, at 105.

26. Tarrow, supra note 5, at 22; Nancy Flowers, How to Define Human Rights Education? a Complex Answer to a Simple Question, in International Perspectives in Human Rights Education Vol. 112 (Viola B. Georgi \& Michael Seberich eds., 2004).

27. FLOWERS, supra note 7 , at 40 .

28. Tibbitts, Human Rights Education, supra note 3, at 101-02 (citing Felice Yeban, Building A Culture of Human Rights: Challenge To Human Rights Education in 21st Century, in Human Rights Education Pack, Asian Regional Resource Center for Human Rights Education (1995)). 
HRE content and constituencies may differ across nation-states, and scholars have conceptualized the different forms of education that are emphasized across these contexts. The following diagram from the Council of Europe's manual Compasito offers a glimpse into the over-arching values of HRE (assumed to be common for all programs), types of educational programs, and the generations of human rights (a concept that has been critiqued by scholars in the field of human rights law, but that is still widely utilized).

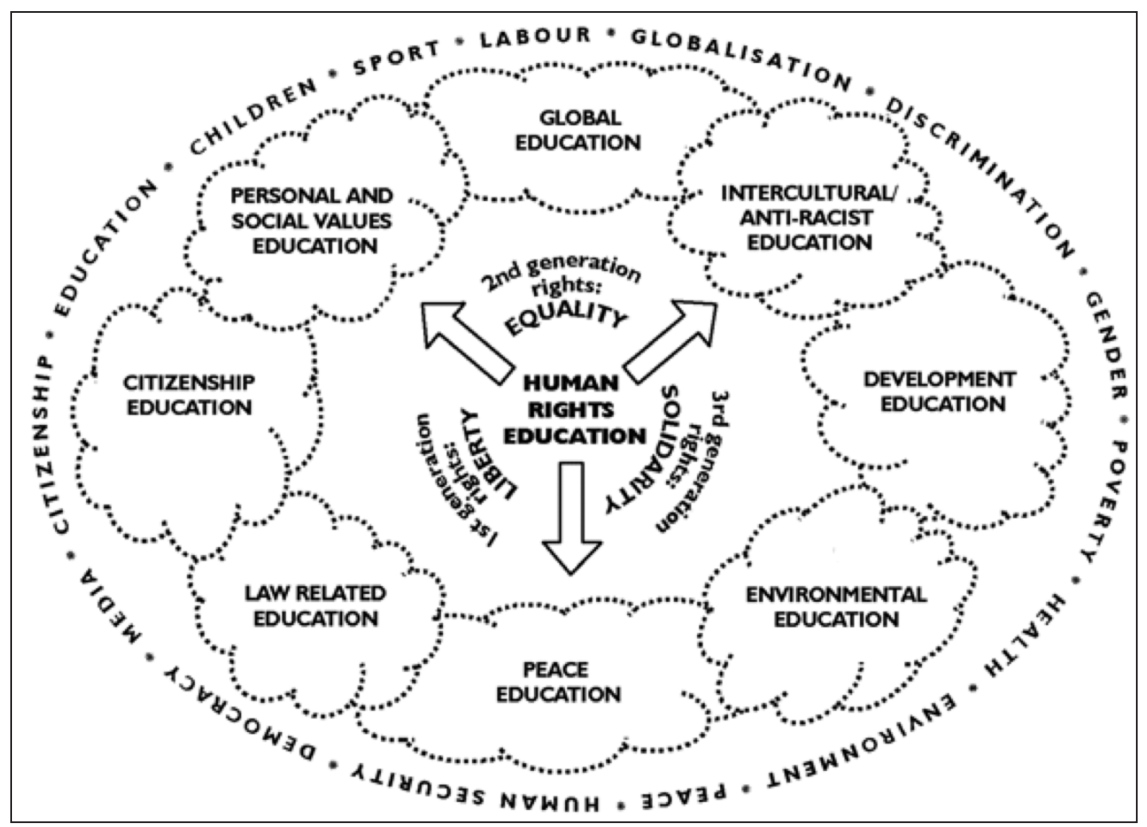

Figure 1: Types of Human Rights Education (HRE), Compasito Manual ${ }^{29}$

The division among generations of human rights resonates with differentiations among countries with different income levels and political orientations. While Figure 1 offers a comprehensive picture of HRE, the extent to which such a holistic perspective is incorporated and implemented in programs and curricula is unclear. What the diagram does offer is a conceptualization of the range of ways in which HRE is understood and practiced, however partially, based on location, ideology, and desired outcomes.

29. Nancy Flowers et al., Council of Europe, Compasito: Manual on Human Rights Education for ChILDREN 30 (2007). 
Debates on the relationship between NGOs and the state in HREalthough often advanced by these two entities independently-also color meanings ascribed to HRE. Many scholars have noted a central tension in the field of HRE that involves the historic role of NGOs as pioneers of the educational reform and the international adoption of HRE measures through the UN, an institution made up of member states working through national level reform. ${ }^{30}$ While the United Nations' endorsement of HRE has resulted in greater coordination, funding, and legitimacy for NGOs working in this area, ${ }^{31}$ the collaborative process with national governments has posed a potential dilemma. HRE has often grown out of human rights legal, advocacy, and activist work of NGOs that place their members in direct confrontation with state forces; this conflictive relationship with the state may prove difficult to surmount when the same organizations attempt to introduce HRE in government schools, as many NGOs have sought to do. While much HRE falls outside the domain of formal schooling and is accomplished through community education or training programs for professionals - such as judges, police, lawyers, armed forces, and health-workers, among others-all of these actors are no doubt integrally involved professionally with the state, as are teachers in government schools.

While UN agencies take a very favorable view of national governments' independent adoption of comprehensive human rights content and pedagogy, scholars such as Sonia Cardenas have a more skeptical perspective on the role of the state in advancing HRE that may work against its own interests:

While in principle virtually everyone takes for granted the benefits of HRE, such endeavors can be potentially costly from the perspective of a state. Human rights education is inherently revolutionary: If implemented effectively, it has the potential to generate social opposition, alongside rising demands for justice and accountability. ${ }^{32}$

Cardenas sees the state as resistant to incorporating HRE because of "rising demands" related to justice from those educated about human rights. ${ }^{33}$ Other scholars in education, however, have suggested that the form of HRE, or any global education reform, that gets incorporated into national textbooks and local practice may be very different than that originally conceptualized since reforms often go through a process of "decoupling." ${ }^{34}$ In other words, these scholars assert that by the time human rights content gets incorporated into

30. Sonia Cardenas, Constructing Rights? Human Rights Education and the State, 26 INT'L Pol. SCI. Rev. 363, 364 (2005).

31. Suárez, supra note 19.

32. Cardenas, supra note 30.

33. Id

34. John W. Meyer \& Brian Rowan, The Structure of Educational Organizations, in ENviRONments and Organizations 217, 221-222 (J. W. Meyer, B. Rowan, \& W.R. Scott eds., 1978). 
textbooks, it may be altered such that it loses its activist-oriented approach, as human rights are presented as decoupled from the struggles that have achieved greater respect for rights. Indeed, these processes of adaptation can generate greater variation among HRE initiatives if pressure from above de-politicizes HRE and pressure from below attempts to maintain an integral link of HRE to social justice struggles. As such, the following section unpacks the different ideological bases of human rights education.

\section{IDEOLOGICAL ORIENTATIONS AND OUTCOMES OF HRE}

As HRE has been adopted and elaborated upon by more and more educational stakeholders, HRE can no longer be characterized as a singularly understood practice. Furthermore, the varied ideological content of these programs appears to reflect where such programs locate themselves in relation to local, national, and international sites of power-not geography or nationhood understood in any simple, homogenous sense. An elite private school and a school serving a marginalized indigenous community in the same neighborhood may both offer human rights education, but their approaches may vary widely based on the material realities of each group, the manner in which HRE is introduced, and the anticipated outcome. Moving beyond nation-centered understandings of human rights, a limitation often reinforced by the organization of the UN system, helps to underscore the ways that HRE may differ in approach, definition, and desired outcomes.

The model presented in Table 1 distinguishes between three distinct types of HRE. Each of these forms of HRE is not mutually exclusive with the others, but rather offers a way to conceptualize the primary reason for the introduction of HRE, since it generally responds to some perceived need in a particular educational system, program, or school. While the goals and objectives of HRE can embody aspects of any of the three approaches, this article argues that the ideological orientations of most HRE initiatives are generally rooted in one of the following three categories: (1) HRE for Global Citizenship; (2) HRE for Coexistence; or (3) HRE for Transformative Action. ${ }^{35}$

HRE for Global Citizenship seeks to provide learners with membership to an international community through fostering knowledge and skills related to universal values and standards. HRE for Coexistence focuses on

35. Marie-Bénédicte Dembour's distinction between four schools of human rights scholars offers useful insight into how HRE may also be differentially conceived. While "protest" scholars may be more likely to align with HRE for Transformative Action, "deliberative" and "natural" scholars may be more inclined towards HRE for Global Citizenship. See Marie-Bénédicte Dembour, What Are Human Rights? Four Schools of Thought, 32 Hum. RTs. Q. 1, 1-20 (2010). 
the inter-personal and inter-group aspects of rights and is usually a strategy utilized where conflict emerges not from absolute deprivation, but from ethnic or civil strife. The third approach, HRE for Transformative Action, usually involves learners who are marginalized from economic and political power and for whom HRE includes a significant process of understanding their own realities. This approach is most akin to Paulo Freire's process of developing a critical consciousness and what Meintjes terms a "critical human rights consciousness." ${ }^{136}$

In HRE scholarship, many programs appear to espouse all three outcomes and involve transformative action, but as funding agencies promote and national authorities adopt HRE, various definitions are employed that may differ from some scholars' belief that all HRE is "inherently revolutionary." ${ }^{37}$ While global citizenship and coexistence are certainly worthy goals in their own right, distinguishing the forms of HRE can also become a way of thinking about the differentiated ways that HRE may be adapted in the context of local settings, funding availability, and the ideology of those implementing the program. Table 1 therefore outlines varied ideological approaches to HRE.

Table 1 presents different forms of HRE that approach content, pedagogy, and action in distinct ways. Each of these categories is valuable and the schema proposed is merely a means of sorting programs to better understand their vision, methodology, and approach.

The first model, HRE for Global Citizenship, presents international standards as the ideal: repositioning learners as members of a global community instead of simply as national citizens. Content may include treaties and conventions, the words and practices of national and international leaders and movements, and a history of human rights. Values and skills that are imparted in such an approach include empathy and compassion. Resultant actions may include letter-writing, fundraising for services addressing basic needs of those less fortunate, and a model UN or other simulations that prepare learners for potential participation in such international fora in the future.

This brand of HRE seeks to cultivate vibrant global citizenship, a goal seen as beneficial on its own terms. There are many conceptualizations of education for global citizenship, ${ }^{38}$ and most share an emphasis on interdependence, global knowledge, and a commitment to counter injustice wherever in the world it may take place. These principles are rooted in a cosmopolitan ethic that is often linked to universal notions of human rights, but also dis-

36. Paulo Freire, Pedagogy of the Oppressed (Myra Bergman Ramos trans., 1970); Meintjes, supra note 5 , at 78 .

37. Cardenas, supra note 30 , at 364 .

38. See Lynn Davies, Global Citizenship Education, in Encyclopedia of Peace Education, supra note 3, at 109; Educating Citizens for Global Awareness (Nel Noddings ed., 2005). 


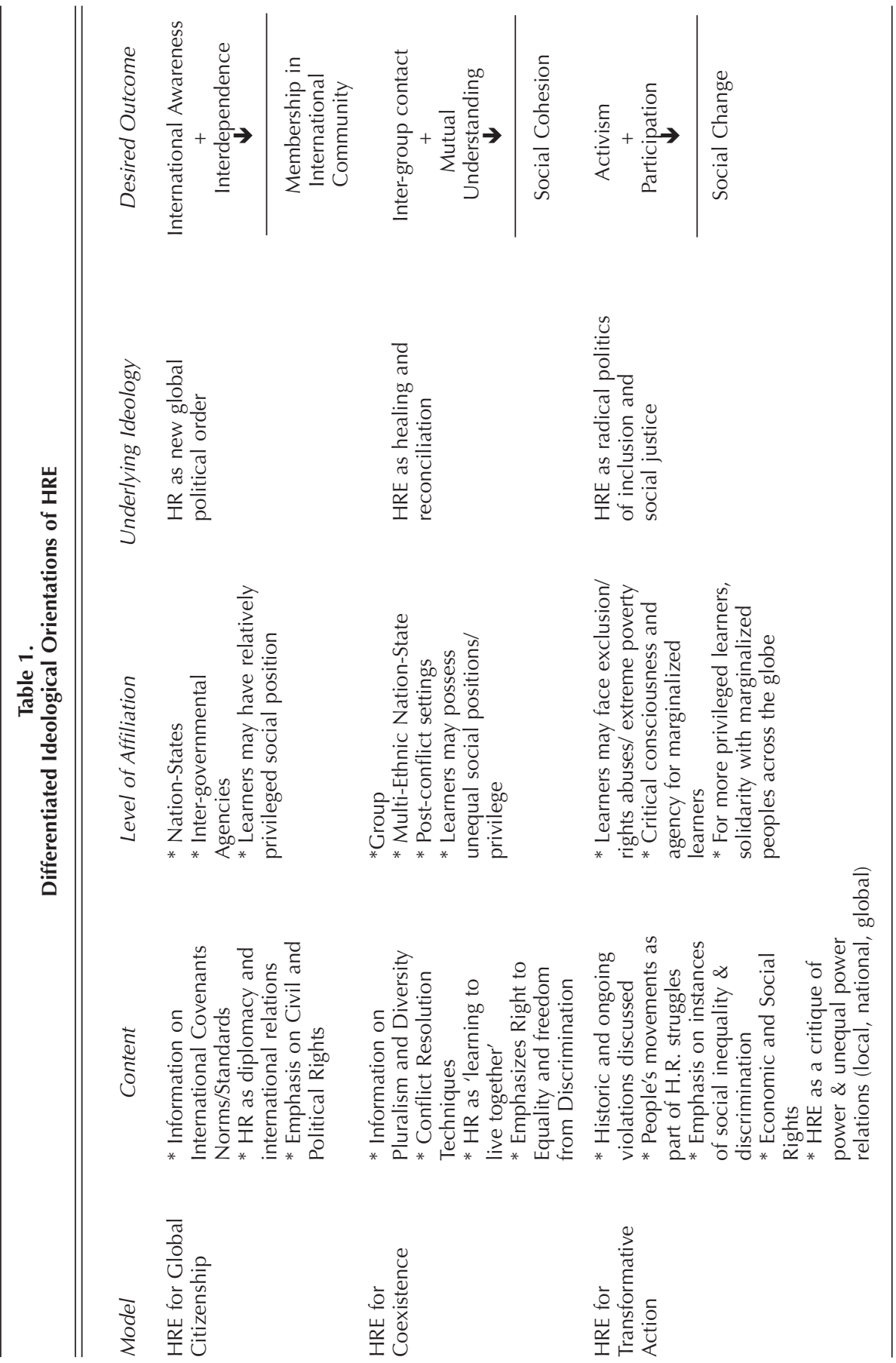


cussed vis-à-vis the interplay between global and local forces; for example, philosopher Kwame Anthony Appiah's notion of "rooted cosmopolitanism" acknowledges interdependence beyond one's own kin as well as the possibilities for mutual learning that diversity presents. ${ }^{39}$ Global citizenship, and arguably HRE initiatives that have this as their desired outcome, are aligned with cosmopolitanism and the increasingly de-territorialized conception of universal rights.

Given the rise in rights discourse at the international level, scholars have noted the worldwide rise in human rights content in textbooks around the globe with an increasing emphasis on individual rights and personal agency as presented in the subjects of history, civics, and social studies. ${ }^{40}$ As such, HRE for Global Citizenship's emphasis on individual rights as part of an international community may or may not be perceived as a direct challenge to the state. With the rise in cosmopolitanism and global citizenship in textbooks, ${ }^{41}$ students interested in human rights are introduced to a framework that can spur further independent investigation into concepts, movements, and local struggles.

HRE for Coexistence presents information related to "other-ed" groups, often in post-conflict settings, that may have been silenced in previous historical narratives in an effort to reexamine and come to terms with histories of violence. This approach emphasizes the role of minority rights and pluralism as part of the larger human rights framework. ${ }^{42}$ Information related to each group is taught as a way of creating greater empathy and understanding. In some cases, educators may search for evidence of collaboration and cooperation, rather than competition in the past to re-frame historical understandings of inter-group conflict, recognizing the role that the teaching of history has played in inter-ethnic violence in various locales. ${ }^{43}$ Values and skills may be related to conflict transformation, respect for differences, mutual understanding, and dialogue. Action may include learning about other groups, inter-group events and interactions (such as encounter camps like Seeds of Peace), and exchanges for greater understanding across groups. ${ }^{44}$

Initiatives towards coexistence, whether labeled peace education or human rights education, generally draw upon the contact hypothesis, a theory

39. Kwame Anthony Appiah, Cosmopolitan Patriots, 23 CRITICAL InQUIRY 617 (1997).

40. Meyer, Bromley \& Ramirez, supra note 2.

41. Patricia Bromley, Cosmopolitanism in Civic Education: Exploring Cross-National Trends, 1970-2008, 12 Current Issues Comp. Educ. 33 (2009).

42. See generally K. Peter Fritzsche, Tolerance Education and Human Rights Education in Times of Fear: A Comparative Perspective, in Educating Toward a Culture of Peace 297 (Yaacov Iram, Hillel Wahrman, \& Zehavit Gross eds., 2006).

43. Sarah Warshauer Freedman, et al., Teaching History after Identity-Based Conflicts: The Rwanda Experience, 52 Comp. Educ. Rev. 663, 666 (2008).

44. Marieke van Woerkom, Seeds of Peace: Toward a Common Narrative, 102 New Dir. Youth Dev. 35 (2004). 
developed by Gordon Allport in the field of social psychology. ${ }^{45}$ He argued that intergroup contact, operating within certain parameters, could play an important role in reducing prejudice and stereotypes. Allport contended that contact alone would not be enough to achieve positive changes, but that intergroup interactions could bring about desired effects when the two parties held equal status, cooperated towards common goals, and participated in an institutional climate that valued integration. Scholars have built on Allport's theory over the past six decades suggesting various modifications, such as the need to prioritize individual rather than group characteristics so as not to reify difference, ${ }^{46}$ but his ideas remain influential in guiding the philosophy of encounter camps, dialogue groups, integrated education, and post-conflict human rights education initiatives across the globe. ${ }^{47}$

HRE for Transformative Action reflects a politically radical approach to the analysis of historical and present conditions and the need for action to rectify the often-wide gap between current realities and human rights guarantees. HRE for Transformative Action is implicitly and explicitly concerned with relationships of power. As Indian legal scholar Upendra Baxi has noted, human rights (and human rights education) have long been characterized by the "continuing confrontation between emergent cultures of rights and entrenched cultures of power." 48 This concern with power and asymmetries in power relations translates into an analysis of how human rights norms and standards are often selectively respected based on communities' varied access to resources, representation, and influence.

HRE for Transformative Action is rooted in the concepts of agency and solidarity. For learners who may be victims or witnesses to frequent abuses, this type of human rights education can foster a sense of transformative or strategic agency defined by educational scholars as a larger critique of one's social realities and a willingness to act upon them. ${ }^{49}$ For those who may not

45. Gordon W. Allport, The Nature of Prejudice 261-81 (1954).

46. Groups in Contact: The Psychology of Desegregation 281-302 (Norman Miller \& Marilynn Brewer eds., 1984).

47. See, e.g., Anna Ohanyan \& John E. Lewis, Politics of Peace-Building: Critical Evaluation of Interethnic Contact Peace Education in Georgian Peace Camp, 1998-2002, 30 PEACE \& Change 57 (2005); van Woerkom, supra note 44; Saloshna Vandeyar \& Heidi Esakov, Color Coded: How Well do Students of Different Race Groups Interact in South African Schools?, in Addressing Ethnic Conflict through Peace Education: International Perspectives 63 (2007).

48. Upendra Baxi, Human Rights Education: The Promise of the Third Millennium?, in Human Rights Education for the Twenty First Century, supra note 5, at 142.

49. See Michael W. Apple, Reproduction and Contradiction in Education, in Cultural AND Economic Reproduction in Education: Essays on Class, Ideology, and the State (Michael W. Apple ed., 1982); Stanley Aronowitz \& Henry A. Giroux, Education Still Under Siege (1993); Freire, supra note 36; Henry A. Giroux, Schooling and the Struggle for Public Life: Critical Pedagogy in the Modern Age (1988); Pedro A. Noguera, City Schools and the American Dream: Reclaiming the Promise of Public Education (2003). 
be directly affected by abuses, or who may witness abuses but hold some relative privilege in a given situation (for example boys versus girls from a marginalized group), HRE for Transformative Action may foster a sense of solidarity or "coalitional agency" (which may also be transformative). ${ }^{50}$ Willingness to act with or on behalf of victims is guided by the belief that injustice faced by any target group represents a threat to the society as whole.

HRE for Transformative Action is primarily concerned with understanding how power relationships are structured, and the possibilities for greater collaboration across groups that might effectively result in greater respect for human rights. Meintjes notes that "[h]uman rights are inherently about relationships; and whatever their nature, whether they concern the power relations between individuals, groups, society, and/or the state, they are inevitably always dynamic and relative. ${ }^{\prime 51}$ As such, for the two different constituencies of marginalized and privileged learners (that are not static and may change from situation to situation), this type of HRE prioritizes an analysis of power and how one might act in the face of injustice. Thus, content might include examples of social injustice that learners collect from their own homes or communities; values and skills might include solidarity with victims, equality, and justice; and actions might include collective protest, intervening in situations of abuse, and joining NGOs or social movements to advance greater participation and inclusion.

Given the emphasis of previous models of HRE on the nation-state as determinant of the type of HRE adopted, this article examines three case studies of NGOs undertaking HRE at different levels and with distinct ideological orientations in one nation state, India. Multiple efforts towards HRE exist in present day India from national level discourse about its adoption in textbooks and teacher education, to grassroots school-based and after-school HRE instruction, to university-level human rights courses and degrees. The following sections describe three initiatives carried out by NGOs that highlight different ideological approaches to HRE, and present the rationale for their classification in an attempt to highlight the flexibility of HRE in responding to distinct conditions and orientations of stakeholders within nation-states. The data presented below come from document review, interviews, observations, and focus groups as part of a thirteen-month qualitative study carried out by the author on HRE in India.

50. Coalitional agency is defined by feminist scholars Karma Chavez and Cindy Griffin as a relational process in which social change is affected collectively and "necessitates seeing people, history, and culture as inextricably bound to one another." See Cindy L. Griffin \& Karma R. Chávez, Power, Feminisms, and Coalitional Agency: Inviting and Enacting Difficult Dialogues, 32 Women's Stud. Сомm. 1, 8 (2009).

51. Meintjes, supra note 5, at 74 . 


\section{HRE FOR GLOBAL CITIZENSHIP: THE INDIAN INSTITUTE OF HUMAN RIGHTS}

[T] he rise of human rights education is linked closely to processes of globalization over the period since the Second World War, and particularly in the most recent decades. A global society has been constructed and imagined during this period. This is a society in which individual persons are both entitled members and proactive agents. Human rights education . . . reflects both this developing emphasis on world citizenship and the strong assumption of personal commitment required for global citizenship. ${ }^{52}$

The Indian Institute of Human Rights' (IIHR) mission is to provide education in human rights through a two-year distance learning course offered as an undergraduate and graduate level diploma for students throughout India and, increasingly, across the globe..$^{53}$ The Institute was founded in 1999 and primarily concentrates on offering human rights courses, as well as organizing periodic conferences and workshops related to human rights. ${ }^{54}$ The goals of the two-year course are, among others, "[t]o ensure comprehensiveness . . . of national, regional and international perspectives related to human rights" and "[t]o examine the . . . linkages between human rights and democracy, pluralism, development, ... . [and] peace ... at the national and international levels." ${ }^{155}$ Among its students are police, military personnel, diplomats, NGO personnel, homemakers, graduate and undergraduate students, and teachers. ${ }^{56}$ The motivations for taking the course range from personal and professional interests, to a belief that knowledge of human rights will result in greater job prospects or a promotion in one's current field. ${ }^{57}$

The design of the two-year course is tailored to make it accessible to as many students as possible. ${ }^{58}$ Through distance learning, a process in which books and assignments are sent through the post, even students without access to computers can participate in the course. ${ }^{59}$ Exam centers are located throughout India and overseas in cooperating embassies, high commissions, and schools. ${ }^{60}$ Once a student enrolls in either the diploma or post-graduate course, she receives forty books on different aspects of human rights and

52. Ramírez, Suárez \& Meyer, supra note 1, at 36.

53. Interview with Dr. Rahul Rai, Director of the Indian Institute of Human Rights, in New Delhi, India (18 Nov. 2009).

54. Id.

55. Indian Institute of Human Rights, Aims and Objects, available at http://www.rightsedu. net/aims.htm.

56. Interview with Dr. Rahul Rai, supra note 53.

57. Id.

58. Id.

59. Id.

60. Id. 
pursues coursework independently during the two-year period. ${ }^{61}$ The cost of the course is also quite accessible as compared to fees for higher education in India; the entire course (including books) costs 16,025 Rupees (approximately US \$355) for Indian students and \$715 for students outside of India. ${ }^{62}$ Of the 50,000 students, approximately 60 percent are working professionals, while 40 percent are students who may be completing other courses concurrently. ${ }^{63}$ The flexibility of course design has meant that large numbers of students from various backgrounds have been able to participate; indeed, IIHR director Dr. Rahul Rai notes that the age of students in the course ranges from twenty-one to eighty-six. ${ }^{64}$

Course content focuses primarily on various aspects of international human rights standards, case studies of violations, and a field-based report/ thesis about an actual organization working for human rights. Over the six trimesters that the course is conducted, different topics are covered in sequence as the following table summarizes:

Table 2.

Indian Institute of Human Rights Syllabus

Trimester \& Theme

I. Conceptual and Theoretical Understanding of Human Rights

II. Systems, Organizations, and Instruments of Human Rights

III. Contemporary Human Rights Situations and Issues
Topics Covered

$>$ Introduction to Human Rights

$>$ Principles and Theories of Human Rights

$>$ Culture, Wisdom, Religion, and Human Rights

$>$ International Relations, Democracy, and Human Rights

$>$ Systems for Protection of Human Rights

> Organizations Related to Human Rights

$>$ Instruments of Human Rights and Covenants

$>1993$ Vienna Declaration and Programme of Action

> Human Rights in Global and Regional Perspectives

$>$ Promotion, Protection of Human Rights, and Prevention of its Violations

$>$ State of Human Rights in India

Refugees, Displaced Persons, Immigrants, and Asylum

61. Id.

62. Indian Institute of Human Rights, Fee, Syllabus, and Books, available at http://www. rightsedu.net/fee.htm.

63. Interview with Dr. Rahul Rai, supra note 53.

64. Id. 
Table 2. Continued

Indian Institute of Human Rights Syllabus

\section{Trimester \& Theme}

IV. Specialization Course (Students can choose from one of the areas)

V. Awareness, Teaching, Research, and Implementation

VI. Report Writing and Thesis Preparation

\section{Topics Covered}

Concept Specific Themes in Human Rights (Environment, Economic, and Social Rights)

$>$ Action Specific Themes in Human Rights (Activism, NGOs, International Law) $>$ Issue Specific Themes in Human Rights (Children's Rights, Women's Rights, Religion, Population)

$>$ Legislation Specific Themes in Human Rights (International, Regional, National Law)

$>$ Refugee Specific Themes in Human Rights (Refugee law, UNHCR, Refugees in South Asia)

$>$ Human Rights Education, Teaching, and Training

> Human Rights, Peace, Non-Violence, and Conflict Resolution

$>$ Implementing Human Rights Standards and Required Legal Aid, Remedies, and Reforms

$>$ Role of Judiciary, Public Interest Litigation, and Media

Field Report

Study Report

Case Study Report

Master's Thesis

The topics covered offer students a comprehensive overview of human rights, and one unit in the fifth trimester focuses on teaching students specifically about human rights education efforts. Students learn international standards and covenants for a more information-oriented approach that will, ideally, lead to attitudinal and behavior changes. The scope of IIHR's work in more than fifty countries and their flexible design is an impressive example of a broad-based HRE initiative. Armed with knowledge of human rights and a two-year induction as members of a global community, participants may be more attuned to human rights in whatever profession they find themselves in. While IIHR offers an example of HRE for Global Citizenship, other Indian NGOs are working within different ideological frames and engaging other forms of human rights learning. 


\section{HRE FOR COEXISTENCE: THE CENTRE FOR SOCIAL JUSTICE'S HRE PROGRAM}

A common impulse after intergroup conflict-whether international, interethnic, or interracial-is to call for education. Education offers the chance to shape minds, hearts, and behaviors of succeeding generations. Educational responses express this hope: If only we educated young people to respect others; to understand the costs of group hatreds; to make friends, not stereotypes; to know tools for resolving disputes, to choose to stand up to demagogues, to be peacemakers, then we could hope to prevent future violence and future atrocities. ${ }^{65}$

The Centre for Social Justice (CSJ) was established in 1994 to provide legal assistance to marginalized communities through representation, paralegal training, and advocacy. ${ }^{66}$ Following the 2002 communal riots between Muslims and Hindus in Gujarat, CSJ began carrying out a formal school-based "Education for Human Rights" program. ${ }^{67}$ While differing accounts exist of what triggered the conflict, the result was that during nearly four months of violence, 1,180 people were killed (about three times more Muslims than Hindus) and another 2,500 injured. ${ }^{68}$ Human rights organizations have noted state complicity in the inter-religious violence as police stood by and did not intervene on behalf of victims who were raped, tortured, and killed. ${ }^{69}$ At the height of the violence, some 125,000 (mostly Muslims) were displaced from their homes and living in camps, and while most have returned, many have still not been able to return to homes that were burnt down or destroyed. ${ }^{70}$ For some human rights NGOs, school-based education for human rights emerged as an important tool to attempt to eradicate the roots of stereotypes, hatred, and separation that fuelled the violence. ${ }^{71}$

The Education for Human Rights program of the CSJ emphasizes diversity, dignity, equality, and justice. ${ }^{72}$ The program operates in 110 schools in the fifth, sixth, and seventh grades in eight districts of Gujarat and aims for

65. Martha Minow, Education for Co-Existence, 44 Ariz. L. Rev. 1, 2 (2002).

66. Interview with Nupur, Executive Director of the Centre for Social Justice, in Ahmedabad, India (9 Dec. 2009).

67. Id. The Centre for Social Justice uses the term "Education for Human Rights" rather than "Human Rights Education" to denote a more attitudinal and values-based approach rather than merely content or information on human rights.

68. Gujarat Riot Death Toll Revealed, BBC News, 11 May 2005, available at http://news. bbc.co.uk/2/hi/south_asia/4536199.stm.

69. Human Rights Watch (HRW), "We Have No Orders To Save You:" State Participation and Complicity in Communal Violence in Gujarat, 14 HRW 3(c) 5(2002), available at http:// www.hrw.org/legacy/reports/2002/India.

70. Christophe Jaffrelot, Communal Riots in Gujarat: The State at Risk?, 17 Heidelberg Papers in South Asian and Comparative Politics 6 (2003).

71. Interview with Nupur, supra note 66.

72. Id. 
students to have instruction for two periods per week over three years. ${ }^{73}$ Teachers undergo training to encourage a re-analysis of issues of identity based on caste, gender, and religion, among others. ${ }^{74}$ While the population is different in each district-and this means a modified approach based on the respective constituency-what is common across CSJ's Education for Human Rights program is its emphasis on diversity and pluralism as a core component of education for human rights, participatory methodology for instruction, and the creation of teaching and learning materials that are context-specific and designed by the teachers themselves. In its modules, which are called "saptrangi" (rainbow) volumes one and two, stories are given that highlight gender equality, pluralism, diversity, citizenship, and peace. ${ }^{75}$ In one story, the underlying humanness of two children (one Hindu and one Muslim) is highlighted despite differences that arise between their communities (excerpted in Figure 2). ${ }^{76}$ Other stories relate to gender inequities, caste discrimination, and other forms of social exclusion. ${ }^{77}$ Following each story are reflection questions that examine the status quo and encourage students to consider alternatives to the stereotypes and discrimination that pervade their social milieu. ${ }^{78}$

\section{Figure 2: Story from Saptrangi Module ${ }^{79}$}

This is a story of two friends living in a town called Chandanpur: Ramesh, who is Hindu, and Rahim, who is Muslim. They are close friends. Together they own a clothing shop, which is always busy with customers. They earned well from the business of the shop and slowly, they became the number one shop in town. Their business worked on good faith. No one questioned each other's integrity. Everything was working in their favor.

But this was not acceptable to some people in the town. They could not tolerate the progress of two friends from different religions. So slowly they started talking to Ramesh, saying that he should not trust a Muslim: "They are not reliable people; they will ditch you at the last moment". Ramesh was not able to understand the intentions of these people and believed whatever they said.

73. Id.

74. Id.

75. Centre for Social Justice, HRE Manual, available at http://www.centreforsocialjustice. net/hrmanual.html.

76. Id

77. Id.

78. Id.

79. People's Watch, Institute for Human Rights Education, Schooling for Justice and Human Rights (2008). 
Slowly, because of this prejudiced mindset, the shop was divided and the friends became enemies.

Rahim was very sad because of this. He started his own new shop and Ramesh stayed in the old shop. One day, Rahim was attending to a customer in his shop when he saw a motorcycle come from behind and hit Ramesh. Ramesh fell flat on the road. No one came to his help. Rahim immediately jumped out of his shop and ran towards Ramesh. He took him to the hospital. The doctor said Ramesh was critical and would need blood. Rahim knew that their blood groups were the same so immediately agreed to give his blood. Because of the timely treatment and the blood given by Rahim, Ramesh recovered fast.

It was a moment to enjoy when Ramesh apologized to Rahim for his behavior and mistrust and-seeking his forgiveness-proposed to again join hands as friends. Both of them had tears of joy in their eyes and they strongly embraced each other.

\section{Points of Discussion}

* Is there any difference physically between human beings?

* What are the different communities and religions that are in your village/city?

* Are these people the same or different?

* What do your parents say about the communities or religions other than yours?

* Do you think that Hindus and Muslims can work together?

* What are the different prejudices that prevail around you for other castes and religions?

* Who told you about them?

The inter-religious violence in Gujarat ${ }^{80}$ perhaps shapes some of the outcomes of Education for Human Rights carried out in schools by CSJ. In a situation where communal tensions still remain high, teachers and students reported that Education for Human Rights had resulted in a greater humanization of the other group. ${ }^{81}$ Specifically, one teacher noted that after the introduction of the Education for Human Rights program, students would visit each other's

80. HRW, We Have No Orders to Save You, supra note 69.

81. Interview with students and teachers of the Education for Human Rights program, in Anand District, India (10 Dec. 2009). 
homes (having to convince unwilling parents if need be), which was not a common practice prior to the introduction of the program. ${ }^{82}$

CSJ's Education for Human Rights program focuses on issues of identity and diversity as a starting point for understanding human rights and citizenship. ${ }^{83}$ The approach examines multiple identities and seeks to explore the commonalities among different groups, dispelling myths and stereotypes that can lead to violence, conflict, and rights abuses.$^{84}$ In the three-year program, the first year (fifth standard or grade) focuses on stereotypes, prejudices, rights, and discrimination. ${ }^{85}$ In year two, sixth standard students examine peace, conflict, conflict resolution techniques, democracy and diversity. ${ }^{86}$ In year three, students develop and carry out projects that are intended to extend their learning from their schools into society. ${ }^{87}$ While CSJ aims to inculcate a variety of values and skills, the emphasis on HRE for coexistence and diversity is among the highest priorities of the educational initiative.

\section{HRE FOR TRANSFORMATIVE ACTION: THE INSTITUTE OF HUMAN RIGHTS EDUCATION}

Radical education of HRE needs a radical pedagogy. The classroom, as it exists today, is ill-suited to transact a humanizing education. Classroom relations are power relations, with the teacher wielding absolute authority over the students within its confined space, while she herself is a low level functionary in bureaucratized, elite-driven, elite-centred education system. The curriculum, evaluation methods, a fiercely competitive culture, and concepts of discipline militate against nurturing a human rights and democratic culture. Human rights education needs to be a child-centred education, respecting the child's role as constructor of knowledge rather than treating her as a passive recipient of information. The child who comes into a class is treated as an empty vessel, into which ready-made, pre-cooked knowledge is poured. Human rights education cannot be imparted [only] within the four walls of the classroom. It has to be learnt, out in the world, in the midst of people, particularly among victims of injustice and rights violations. It cannot stop with acquiring information, but should lead to courageous and collective action in solidarity with victims. ${ }^{88}$

\footnotetext{
82. Id.

83. Interview with Nupur, supra note 66 .

84. Id

85. Id

86. Id.

87. Id

88. V. Vasanthi Devi, Institute of Human Rights Education: India Experience, 10 HRE IN AsIAN SchOols 41 (2007), available at http://www.hurights.or.jp/archives/pdf/asia-s-ed/ v10/04Institute $\% 20$ of $\% 20$ HRE, \%20India\%20Experience-reduced.pdf.
} 
The Institute of Human Rights Education (IHRE), the educational wing of the Indian human rights organization People's Watch, based in the southern Indian state of Tamil Nadu, began operating in 1997 when teachers asked activists at the organization how they might incorporate human rights principles in the classroom. ${ }^{89}$ Starting as an experiment with a handful of schools, the organization developed a curriculum, delivered trainings for teachers, and attempted to translate and expand their human rights work (initially primarily on caste discrimination and police abuse) into a broadbased educational program. ${ }^{90}$ As connections were made with the UN Decade, IHRE was able to gain support by aligning with international efforts to promote human rights and translating these interests into funding for their work..$^{91}$ At the time of this writing, IHRE operates in nearly 4,000 schools in eighteen Indian states. ${ }^{92}$ Textbooks have been developed in multiple regional languages, and more than 300,000 Indian students have participated in a three-year course in human rights. ${ }^{93}$ Year one introduces students to human rights; year two focuses on children's rights; and year three deals with discrimination and inequality. ${ }^{94}$

IHRE's model attempts to offer breadth and depth to human rights education in the schools in which it works. ${ }^{95}$ By securing permission from the government, IHRE has been able to enter into thousands of schools, mainly those serving Dalits (India's formerly and so-called "untouchables"), those considered on the lowest rung of the caste system, and "Adivasi" or students from indigenous "tribes" - both groups comprising the most marginalized sections of Indian society. ${ }^{96}$ IHRE aims to secure two hour-long periods per week in which students in the sixth, seventh, and eighth standards are taught by teachers who are trained by IHRE staff, and who use textbooks developed by affiliated curriculum experts. ${ }^{97}$ Textbooks and trainings in-

89. Interview with Henri Tiphagne, Executive Director of People's Watch, in Madurai, India (15 Feb. 2009).

90. Id.

91. Id.

92. Id.

93. Id.

94. Id.

95. Id.

96. Dalits (literally translated as "broken people") constitute 15 percent of India's population. Human Rights Watch finds that "Entrenched discrimination violates Dalits' rights to education, health, housing, property, freedom of religion, free choice of employment, and equal treatment before the law. Dalits also suffer routine violations of their right to life and security of person through state-sponsored or -sanctioned acts of violence, including torture." See HRW, Hidden Apartheid: Caste Discrimination against India's "Untouchables" (2007), available at http://www.hrw.org/en/reports/2007/02/12/hiddenapartheid.

97. Institute of Human Rights Education, Impact Stories, http://www.ihre.in/dm_documents/ Impact\%20stories/pictures_ihre_IHRE\%20-\%20Impact\%20Stories.pdf [hereinafter IHRE, Impact Stories]. 
clude concepts related to general human rights, children's rights, and issues of discrimination based on caste, gender, religion, ability, skin color, and ethnicity, among others. ${ }^{98}$

Figure 3.

Frequency of Topics and Methods Utilized in IHRE Textbooks ${ }^{99}$

Topics

(In order of frequency, from highest)

1. Poverty/ underdevelopment/ class inequalities

2. Gender discrimination/ need for equal treatment

3. Child labor/ children's rights

4. Caste discrimination/ untouchability/ need for equality

5. Social movements/ examples of leaders and activists

6. Religious intolerance/ need for harmony and pluralism

7. Rights of tribal/Adivasi communities

8. Rights of the disabled and mentally ill

9. Democracy

10. Environmental rights
Methods

(In order of frequency, from highest)

1. Reflective/ participatory in-class exercise

2. Illustrated dialogue or story

3. Community interviews and/ or investigation and research

4. Small group work and discussion

5. Creative artistic expression (drawing, poetry, etc.)

6. Class presentation

7. Inquiry questions \& essay writing

8. Role play, dramatization, song-writing

9. Letter writing to officials

10. School or community campaign

IHRE's approach to educational reform vis-à-vis human rights differs greatly from conventional Indian education. This is especially true in government schools where rampant human rights abuses occur. Such abuses range from corporal punishment, caste discrimination in seating and separation during government-provided school meals, and insufficient and dilapidated facilities (particularly toilets that lead to girls dropping out after they reach puberty). ${ }^{100}$

In a study undertaken by IHRE on ten years of its work in the state of Tamil Nadu and funded by the United Nations Office of the High Commissioner for Human Rights (OHCHR), IHRE cites several instances of impact on teachers and students, most of which have to do with participants

98. Author's own personal analysis of the IHRE textbooks.

99. Topics and methods were analyzed from an English translation of IHRE's textbooks utilized in Tamil Nadu.

100. See Geetha B. Nambissan, Mona Sedwal, Education for All: The Situation of Dalit Children in India, in India Education Report 72 (R. Govinda ed., 2002). 
taking action related to human rights after learning about them. ${ }^{101}$ Of the twenty-five impact stories presented in the over 150 page report, twentythree mentioned knowledge, values, and skills that teachers or students utilized to take some form of action. ${ }^{102}$ The most reported form of impact from HRE was intervention in a an abusive situation: 36 percent of students and 47 percent of teachers noted that they took some action to stop diverse situations related to discrimination, child labor, domestic violence, and infanticide, among others. ${ }^{103}$ Another 36 percent of students and teachers identified that HRE led them to report incidents of abuse to authorities-be they village elders, police, or teachers/headmasters in a school context-to bring about a change to an existing practice. ${ }^{104}$ Another 16 percent raised awareness about a human rights issue, and 8 percent noted an individual change in knowledge or skills but took no specific action per se. ${ }^{105} \mathrm{Ad}$ ditionally, of the twenty-five impact stories, nine (36 percent) involved the HRE teacher or student directly, and the abuse being discussed was in his or her home. ${ }^{106}$ Indeed, repeated focus groups and interviews corroborated that students face tremendous hardships and that HRE had resulted in many of them taking action, whether successful or not, to intervene on their own or others' behalf. ${ }^{107}$ While observations, interviews, and focus groups offer useful data regarding the meanings of HRE and student experiences (and these findings are presented elsewhere), ${ }^{108}$ how an organization, such as IHRE, presents itself and its work-through textbooks, the OHCHR report, and related materials-offers interesting insights into the ideology and the different manifestations of HRE.

While teachers are often discussed in HRE literature as agents who simply transmit human rights instruction, ${ }^{109}$ IHRE focuses on teachers as equally important subjects of human rights education who can go through transformative processes as well as take action, rooted in knowledge and skills, in their own lives as well as those of students and community members. Many of the human rights abuses noted earlier in this article that take place in Indian schools_-primarily gender discrimination, caste discrimination, and

101. HRW, Schooling for Justice and Human Rights, supra note 79.

102. Id.

103. Id.

104. Id.

105. Id.

106. Id.

107. Community interviews and personal research of author.

108. Monisha Bajaj, From "Time Pass" to Transformative Force: School-Based Human Rights Education in Tamil Nadu, India, INT'L J. Educ. Dev. (2010) (doi:10.1016/j. ijedudev.2010.10.001).

109. FLOWERS, supra note 7 . 
corporal punishment-are often perpetuated by teachers. ${ }^{110}$ More than half of the examples of impact listed in IHRE's ten year report are dedicated to the transformation of teachers who, given their relatively respected status in rural areas as part of a minority of literate professionals, can result in effective interventions on behalf of victims, whether the victims are their students or not. ${ }^{111}$

The Institute of Human Rights Education's approach to HRE for Transformative Action is reflected in their reports and textbooks. ${ }^{112}$ In the three textbooks for learners in sixth, seventh, and eighth standards, of the 153 real-life examples utilized (primarily from historical stories and newspaper articles), 86.4 percent relate to social inequalities based on gender, caste, religion, income level, ability, age, or place of birth; of these, 20.5 percent present specific examples of activists and/or movements that have brought about social change through individual or collective action. ${ }^{113}$ The representative examples of human rights violations chosen for national or statelevel textbooks in government or private schools typically do not reflect the graphic descriptions of caste and gender discrimination, child abuse, and social inequalities that fill the pages of IHRE's textbooks. However, for students who witness and hear about such incidents in their daily lives, naming the practices-and providing a framework in which to interpret and condemn such practices-indeed proves to be meaningful for teachers and students alike. Early exposure to abuses for learners who are positioned at the margins of a given society - and in the case of IHRE's constituents, at the very periphery of the global economy-is intended to facilitate a transformative action approach that starts from knowledge and awareness of human rights violations and focuses on the next steps of solidarity, intervention, and activism. ${ }^{114}$

Some of the success in implementation of IHRE's program can be attributed to their working through government-run schools by seeking official permission from senior officials; in such structures, teachers adhere to headmasters who in turn adhere to senior education officials' sanction of the program. Additionally, many children and parents defer to the authority and legitimacy of the material contained in printed textbooks. ${ }^{115}$ Once the

110. Geetha B. Nambissan \& Mona Sedwal, Education for All: The Situation of Dalit Children in India, in InDIA EDUCATION Report 71-84 (2002), available at http://www.doccentre.org/ docsweb/Education/Scanned_material/SC_Analysis.pdf.

111. See Author's personal analysis, supra note 101.

112. Id.

113. Id.

114. IHRE, Impact Stories, supra note 97.

115. See Monisha Bajaj, Teaching to Transform, Transforming to Teach: Exploring the Role of Teachers in Human Rights Education in India Educational Research (forthcoming). 
IHRE textbooks reach the classroom - whether brought about through teachers' interest or the official mandate (or both) - the action-oriented approach seeks to offer marginalized students the tools to understand and to attempt to transform their own social conditions, reflecting the organization's activist ideology and approach.

More radical forms of HRE are criticized for their limited scope and political efficacy. ${ }^{116}$ Yet, while the impact of these groups may not be measured in the wielding of immediate political power, their efficacy should be judged by their success in expanding the ethical horizons of civic discourse and broadening long-term notions of what is considered both politically acceptable and possible. IHRE does both, by expanding understandings of human rights and achieving concrete victories measured by the sheer scope and reach of their program, as well as the considerable instances of impact noted by teachers and students.

\section{CONCLUSIONS}

"Education" is such a full development of human personality as to endow human beings with the power to resist the colonization of the mind by state, civil society, intergovernmental regimes and multinationals.... In this image, human rights education will be a distinctly autonomous, decolonizing, deglobalizing, heretical project in which the very act of learning will be simultaneously an act of insurrection aiming at the dissipation of imposed knowledges. ${ }^{117}$

Models of HRE have generally focused on age, constituency, national political context, or generation of rights to differentiate types of programs. This article argues that ideological variation can also play a significant role in distinguishing HRE initiatives. As Tibbitts notes, HRE is affiliated with different sectors in different societies, but often it also means different things to the distinct individuals and entities promoting it. To some, HRE signals entry into the global community and membership benefits, as has been discussed, for example, in Turkey's national efforts to incorporate HRE in their accession bid to the European Union. ${ }^{118}$ In the Gaza Strip, the United Nations Relief and Works Agency for Palestine Refugees in the Near East (UNRWA) runs a HRE initiative to foster non-violence, conflict resolution, and mutual understanding. ${ }^{119}$ In countries emerging from conflict, HRE em-

116. Cardenas, supra note 30.

117. Baxi, supra note 48 , at 151-53.

118. Neil Hicks, Legislative Reform in Turkey and European Human Rights Mechanisms, 3 Hum. Rts. Rev. 78 (2001).

119. UNRWA, Human Rights Promotion, available at http://www.unrwa.org/etemplate. php?id=92. 
bodies a reconciliation strategy often incorporated into government policy or peace accords as seen in nations as diverse as Guatemala, Cambodia, and Rwanda, among others. ${ }^{120}$

As suggested above, ideology, as much as location or other variables, shapes programmatic approaches to HRE. As historian Paul Zeleza has noted, "the challenge . . . is not to splinter 'The South' into more worlds . . . but to dissolve the very duality of North and South, to conceptualize economic hierarchies and exploitation as much as in spatial and international terms as in social and intranational terms." ${ }^{\prime 21}$ The distance from power may be a more useful predictor of a program's ideological bent and strategy towards HRE rather than geographical location. For example, a HRE program for marginalized youth in New York City public schools, like the Human Rights Activist Project of the youth development organization Global Kids, ${ }^{122}$ may be more closely aligned with the Institute of Human Rights Education in India's HRE for Transformative Action approach with regards to outlook, methodology, and practice than perhaps the Indian Institute of Human Rights' HRE for Global Citizenship approach that utilizes distance learning for post-graduates and professionals. As heightened calls for evaluation are made by scholars and practitioners of $\mathrm{HRE},{ }^{123}$ models for understanding HRE can offer productive frameworks for analyzing its impact as well as the experiences of participants.

Distinguishing approaches to HRE among the categories presented here-for global citizenship, coexistence, and transformative action-is not intended to diminish these efforts. On the contrary, the mutability of HRE is its strength. That different organizations with distinct social bases and

120. See Tania Bernath, Tracey Holland \& Paul Martin, How Can Human Rights Education Contribute to International Peace-Building?, in Current Issues in Comparative Education 14, v. 2 (1999); Freedman et al., supra note 43.

121. Paul Tiyambe Zeleza, The Challenges of Writing African Economic History, in ConTESTED Terrains and Constructed Categories: Contemporary Africa in Focus 59, 74 (George Clement Bond \& Nigel C. Gibson eds., 2002).

122. Global Kids: Developing Youth Leaders for the Global Stage, available at http://www. globalkids.org. Global Kids is a youth development organization based in New York City that runs during and after-school programs to "educate and inspire urban youth to become successful students, global citizens and community leaders by engaging them in academically rigorous, socially dynamic, content-rich learning experiences." Launched in 1989, Global Kids reaches more than 15,000 youth per year through its workshops, online programs, and summer institute. The Human Rights Activist Project (HRAP) is one component of Global Kids' work and brings together urban high school students in New York City throughout the school year to learn about, develop campaigns, and raise public awareness on human rights issues. HRAP also has an international component where students travel overseas to learn about and take action related to critical human rights issues. Id.

123. See Susanne Ulrich \& Florian M. Wenzel, Participatory Evaluation: A Perspective for Human Rights Education (unpublished manuscript), available at http://www.bpb.de/ files/155ALL.pdf. 
worldviews ground themselves in this discourse suggests the richness and possibility of HRE. By better understanding the role of power, inequality, and ideological orientation in driving content, pedagogy, and desired outcome of distinct programs and policies, scholars can develop a more nuanced picture of the vitality and promise of these social constructs and compacts. As HRE becomes more integrated into policy discussions at national and international levels, greater attention to what HRE is, does, and means will be needed to ensure that its practice is developed and adapted to new human rights problems, learning contexts, and social reform initiatives. The confluence of efforts towards HRE, however differently motivated, may serve to advance HRE efforts in a more comprehensive way. The diversity of contexts in which HRE can and has been implemented is indeed a testament to its relevance, adaptability, and promise as a lasting educational reform. 